\title{
Mineral inclusions in diamonds from Karowe Mine, Botswana: examining the mantle sources of a diamond population containing exceptionally large crystals.
}

\author{
Theetso Motsamai ${ }^{1}$, Jeff W. Harris ${ }^{2}$, Thomas Stachel ${ }^{1}$, D. Graham Pearson ${ }^{1}$, John \\ Armstrong ${ }^{3}$ \\ 1 University of Alberta, Edmonton, Canada, motsamai@ualberta.ca, tstachel@ualberta.ca, \\ gdpearson@ualberta.ca \\ 2Universty of Glasgow, Glasgow, UK, Jeff.harris@glasgow.ac.uk \\ 3Lucara Diamond Corporation, Vancouver, Canada, JohnA@namdo.com
}

\begin{abstract}
Introduction
Mineral inclusions in diamonds play a critical role in understanding the relationship between diamonds and mantle lithologies. Here we report the first major and trace element study of mineral inclusions in diamonds from the Karowe Mine (Orapa kimberlite cluster) in north-east Botswana, above the western edge of the Zimbabwe Craton. Our objective is to evaluate the mantle sources associated with a coarse diamond population containing very large gem-quality stones. From a total of 107 diamonds, 134 silicate, 14 oxide and 22 sulphide inclusions were recovered. Assigning the inclusions to principal suites, $55 \%$ of the diamonds classify as eclogitic (59 diamonds) and $43 \%$ peridotitic (46 diamonds). The remaining $2 \%$ consist of one sub-lithospheric diamond, containing a non-touching inclusion pair of majoritic garnet and omphacitic clinopyroxene, and a diamond of likely websteritic association.
\end{abstract}

\section{Analytical Results}

The 35 eclogitic garnets recovered classify into two groups on the basis of $\mathrm{CaO}$ content (Fig. 1): high$\mathrm{Ca}$ garnets contain 7.04 to $16.10 \mathrm{wt} \% \mathrm{CaO}$ and have ranges in $\mathrm{Na}_{2} \mathrm{O}$ and $\mathrm{TiO}_{2}$ between 0.13 to 0.55 wt $\%$ and 0.44 to $1.71 \mathrm{wt} \%$, respectively. The low-Ca garnets range from 3.78 to $5.99 \mathrm{wt} \% \mathrm{CaO}$ with $\mathrm{Na}_{2} \mathrm{O}$ and $\mathrm{TiO}_{2}$ contents vary between 0.07 and $0.24 \mathrm{wt} \%$ and 0.46 to $0.66 \mathrm{wt} \%$, respectively. A total of 39 eclogitic clinopyroxene inclusions span the compositional range from (low-Cr) diopside-augite $(n=16)$ to omphacite $(n=24)$, based on their jadeite component (cut-off value of 0.2 for their molar $2 \mathrm{Na} /(2 \mathrm{Na}+\mathrm{Mg}+\mathrm{Ca}+\mathrm{Fe}))$. They contain variable $\mathrm{Al}_{2} \mathrm{O}_{3}(1.79-15.47 \mathrm{wt} \%), \mathrm{Na}_{2} \mathrm{O}$ (2.03-6.48 wt $\left.\%\right), \mathrm{TiO} 2$ $(0.15-0.84 \mathrm{wt} \%)$ and low $\mathrm{Cr}_{2} \mathrm{O}_{3}(<0.27 \mathrm{wt} \%)$. A cation plot of $\mathrm{Al}$ vs Na shows common excess of $\mathrm{Al}$ over $\mathrm{Na}$ indicative of the presence of a Tschermaks component. In addition to the major eclogitic inclusions, three kyanites were recovered, two colourless and one deep blue. The latter coexisted with an orange garnet and had elevated levels of $\mathrm{TiO}_{2}(0.31 \mathrm{wt} \%), \mathrm{Cr}_{2} \mathrm{O}_{3}(0.17 \mathrm{wt} \%), \mathrm{FeO}(0.34 \mathrm{wt} \%)$ and $\mathrm{MgO}(0.18 \mathrm{wt} \%)$ compared to the two colourless kyanites where these oxides totalled $<0.1 \mathrm{wt} \%$. The associated garnet contained $7.04 \mathrm{wt} \% \mathrm{CaO}$, which is too low for derivation for typical grospydite(value of $>0.5$ at molar calculation $(\mathrm{Ca} / \mathrm{Ca}+\mathrm{Mg}+\mathrm{Fe}))$. In 3 diamonds three pure $\mathrm{SiO}_{2}$ inclusions were found and are assumed to represent primary coesite. They were separately associated with garnet, clinopyroxene and sulphide. The garnet belongs to the low-Ca group, the clinopyroxene to the low-Cr diopside-augite class and the sulphide has a low $\mathrm{Cr}$ content indicative of an eclogitic origin.

In the peridotitic suite, 38 olivine inclusions have Mg\# 92.26 to 94.18 with a mean of 93.09 and a median of 93.11. On the basis of coexisting garnets or Mg-chromites (worldwide, with one exception, associated with lherzolitic inclusions), eight are harzburgitic. Based on their generally similar Mg\# (mean of 93.02 and median of 93.10), the remaining olivines likely also are mainly of harzburgitic paragenesis. $\mathrm{NiO}$ contents in olivine vary between 0.25 and $0.39 \mathrm{wt} \%$ (mean of 0.37 and median of $0.36 \mathrm{wt} \%)$. Garnet inclusions are harzburgitic ( $\mathrm{n}=8$; Fig. 1) and lherzolitic $(\mathrm{n}=1)$, with $\mathrm{Cr}_{2} \mathrm{O}_{3}$ contents ranging between 5.65 and $14.70 \mathrm{wt} \%$ and $\mathrm{CaO}$ varying between 0.91 and $5.68 \mathrm{wt} \%$. Four garnets have very low $\mathrm{CaO}$ contents $(0.91-1.79 \mathrm{wt} \%)$, indicative of potentially dunitic sources. One of these low-Ca garnets is very rich in $\mathrm{Cr}_{2} \mathrm{O}_{3}(14.70 \mathrm{wt} \%$; Fig. 1). All harzburgitic garnets record very low $\mathrm{TiO}_{2}$ contents $(<0.05 \mathrm{wt} \%)$ compared to a single lherzolitic garnet which has elevated $\mathrm{TiO}_{2}(0.24 \mathrm{wt} \%)$. 
The $\mathrm{Cr}_{2} \mathrm{O}_{3}$ contents of the $11 \mathrm{Mg}$-chromites were analysed, two coexisting with olivines, range between 61.83 and $67.28 \mathrm{wt} \%$ and $\mathrm{TiO}_{2}$ varies between 0.06 and $1.12 \mathrm{wt} \%$. All the chromites recorded more than 65.16 wt $\% \mathrm{Cr}_{2} \mathrm{O}_{3}$ and less than $0.40 \mathrm{wt} \% \mathrm{TiO}_{2}$ content, except one with $\mathrm{Cr}_{2} \mathrm{O}_{3}$ of 61.83 wt $\%$ and a high $\mathrm{TiO}_{2}$ at 1.12 $\mathrm{wt} \%$. The six orthopyroxene inclusions recovered have a narrow Mg\# range (93.56-94.53; mean 94.00 and median of 94.04), $\mathrm{CaO}$ contents between 0.31 and 0.62 wt $\%$ and $\mathrm{Al}_{2} \mathrm{O}_{3}$ contents 0.53 to $0.98 \mathrm{wt} \%$. Two of the orthopyroxenes coexist with garnets, one harzburgitic and one lherzolitic. Of the remaining four inclusions (one co-existing with olivine), two can be assigned to the harzburgitic paragenesis based on their high $\mathrm{Mg \#}$ and low $\mathrm{CaO}$ content (see Fig. 14 of Stachel \& Harris, 2008), the other two may be either lherzolitic or harzburgitic. The single Cr-diopside inclusion recovered has an $\mathrm{Mg \#}$ of $93.11, \mathrm{a} \mathrm{Cr}_{2} \mathrm{O}_{3}$ content of $0.54 \mathrm{wt} \%, \mathrm{Na}_{2} \mathrm{O}$ at $0.29 \mathrm{wt} \%$ and $\mathrm{Al}_{2} \mathrm{O}_{3}$ at $0.67 \mathrm{wt} \%$.

The majoritic garnet in the sub-lithospheric diamond has $3.23 \mathrm{Si}$ atoms per formula unit $([\mathrm{O}]=12)$,

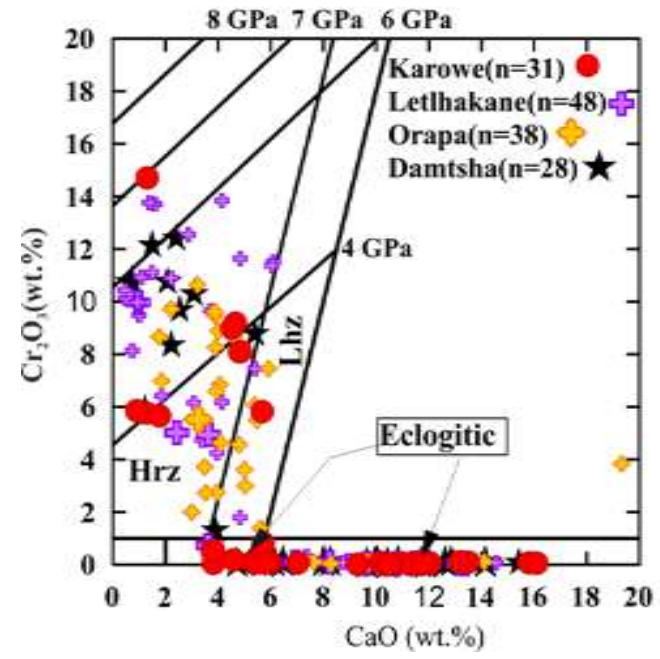

Figure 1: $\mathrm{Cr}_{2} \mathrm{O}_{3}$ vs $\mathrm{CaO}$ diagram for garnets from Karowe and other mines in Orapa cluster(Deines \& Harris,2004; Stachel et al.,2004; Deines et al.,2009) Cr-in-garnets isobars are from Grütter et al.,2006. accompanied by high $\mathrm{Na}_{2} \mathrm{O}(0.76 \mathrm{wt} \%)$ and $\mathrm{TiO}_{2}(1.43$ $\mathrm{wt} \%$ ), and low $\mathrm{CaO}$ (4.60 wt\%). The chemical composition of the accompanying clinopyroxene is omphacitic. A single orthopyroxene inclusion shows an exceptionally low $\mathrm{Mg \#} \mathrm{(56.67),} \mathrm{a} \mathrm{very} \mathrm{high}$ $\mathrm{CaO}$ content $(1.43 \mathrm{wt} \%)$ and elevated $\mathrm{Al}_{2} \mathrm{O}_{3}(0.93 \mathrm{wt} \%)$ and $\mathrm{Cr}_{2} \mathrm{O}_{3}(0.20 \mathrm{wt} \%)$ concentrations. Based on these characteristics the inclusion is tentatively assigned to the websteritic suite, but based on its very high $\mathrm{CaO}$ content could also be of sublithospheric origin.

Of the 22 sulphide inclusions recovered, 20 belong to the eclogitic suite based on low $\mathrm{Cr}$ contents ( $<0.03$ at.\%) and associated inclusion minerals. Only 5 inclusions consisted of monosulphide solid solution (mss), 2 associated with pentlandite and chalcopyrite respectively; 14 were pyrrhotites, of which three coexisted with pentlandite, chalcopyrite and pyrite separately and one with a pyritechalcopyrite assembly; 3 were pentlandites, one being associated with a Ni-Fe alloy. The mss has $\mathrm{Ni}$ contents of 7.33-13.79 at.\%, and the pyrrhotites have a range in Ni from 0.12- 5.21 at.\%. The alloy has a composition of 69.00 a.t $\% \mathrm{Ni}, 29.38$ at.\% Fe and 1.51 a.t\% Co. The two peridotitic sulphides are mss and contain 0.37 at.\% $\mathrm{Cr}$; they were both recovered from the same diamond along with an olivine.

Trace element concentrations were analysed for 12 garnets and 12 clinopyroxenes from the eclogitic suite. The low-Ca $(n=3)$ garnets exhibit steep positive slopes within the $\mathrm{LREE}_{\mathrm{N}}$ and less positive ones at $\mathrm{MREE}_{\mathrm{N}}-\mathrm{HREE}_{\mathrm{N}}$, the latter at about 11 to 13 times chondritic abundances. Six of the high-Ca garnets show steep positive slopes within the $\mathrm{LREE}_{\mathrm{N}}$, but flat distributions between $\mathrm{MREE}_{\mathrm{N}}$ and $\mathrm{HREE}_{\mathrm{N}}$, The remaining three garnets are similar, except that they are slightly enriched in $\mathrm{LREE}_{\mathrm{N}}$. Of the $12 \mathrm{REE}_{\mathrm{N}}$ patterns for eclogitic clinopyroxenes, nine are characterized by a slight positive slope
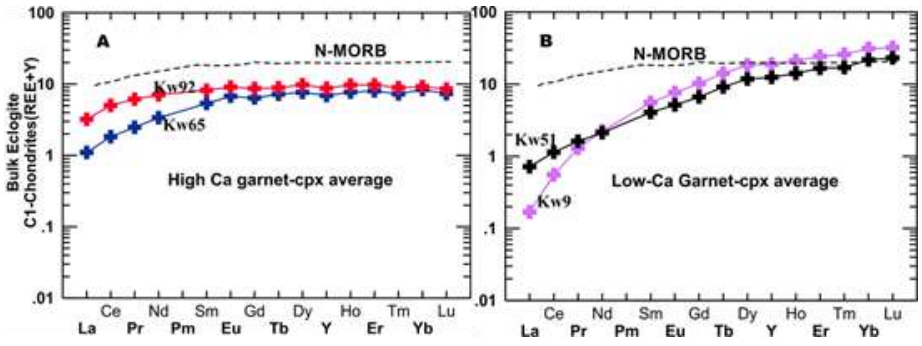

Figure 2: Reconstructed whole-rock REEN for eclogitic bulk rocks associated with high-and low-Ca garnets(assuming grt:cpx=1:1. N-MORB composition is from Sun \& McDonough, 1989. among the LREE $_{N}$ and a slight steady decline within MREE $_{\mathrm{N}}-\mathrm{HREE}_{\mathrm{N}}$ from 10 to about 0.2 to 3 chondritic abundances. Two of the remaining clinopyroxenes have humped patterns, peaking in the LREE $_{\mathrm{N}}$ at about 12 to 99 times chondritic abundances, but thereafter, their slopes are similar to the ones noted above. The last pattern has typical $\mathrm{LREE}_{\mathrm{N}}$ but is depleted in the $\operatorname{HREE}_{\mathrm{N}}$. This sample is the only one to show a positive $\mathrm{Eu}$ anomaly. Four garnet-clinopyroxene pairs from four diamonds were used to reconstruct eclogite bulk rock $\mathrm{REE}_{\mathrm{N}}$ patterns (Fig. 2). They show broadly N-MORB like patterns with 
overall REE depletion for high-Ca garnet associated bulk rocks and prominent $\mathrm{LREE}_{\mathrm{N}}$ depletion for the low-Ca associated bulk rocks. Furthermore, five harzburgitic and one lherzolitic garnet were analysed. The harzburgitic garnets show distinctly sinusoidal $\mathrm{REE}_{\mathrm{N}}$ patterns with strongly variable overall REE contents. The single analysed lherzolitic garnet has a normal $\mathrm{REE}_{\mathrm{N}}$ pattern with flat $\mathrm{MREE}_{\mathrm{N}}-\mathrm{HREE}_{\mathrm{N}}$ at about 3 times chondritic abundance. The majoritic garnet shows a steep negative slope from $\mathrm{LREE}_{\mathrm{N}}$ ( $100 \times$ chondritic) to $\operatorname{HREE}_{\mathrm{N}}$ (at about chondritic abundance)

\section{Geothermobarometry}

Non-touching garnet-orthopyroxene inclusion pairs $(\mathrm{n}=2)$ indicate peridotitic diamond formation at $1060{ }^{\circ} \mathrm{C} / 48.9 \mathrm{kbar}$ and $1090{ }^{\circ} \mathrm{C} / 51.5 \mathrm{kbar}$, i.e. along a $38 \mathrm{~mW} / \mathrm{m}^{2}$ geothermal gradient. This value is slightly below the $\sim 40 \mathrm{~mW} / \mathrm{m}^{2}$ paleogeotherm derived from mantle xenoliths at Letlhakane (Stiefenhofer et al., 1997). Cr-in-garnet barometry (Grütter et al., 2006) indicates peridotitic diamond formation up to a (minimum) depth of up to $220 \mathrm{~km}$ (Fig. 1). Based on Ca-in-opx thermometry, the presumed single websteritic pyroxene last equilibrated at $1380{ }^{\circ} \mathrm{C}$, which suggests derivation from a thermally perturbed lithospheric source or from below the lithospheric mantle. Based on Si excess, the majoritic garnet inclusion derives from a depth of about $361 \mathrm{~km}$.

\section{Discussion and Conclusions}

With few exceptions, the chemical composition of the eclogitic and peridotitic inclusions in Karowe diamonds compares well to previous studies on inclusion-bearing diamonds from other kimberlites in the Orapa cluster (Orapa, Damtshaa and Letlhakane mines). Among the eclogitic garnets, one sample records the highest $\mathrm{TiO}_{2}$ concentration $(1.71 \mathrm{wt} \%)$ yet observed in the Orapa cluster and the same garnet is aslo enriched in LREE and $\mathrm{Zr}(130 \mathrm{ppm})$. This indicates a higher metasomatic activity for Karowe eclogitic diamond sources. In the peridotitic garnets, one Karowe inclusion shows a much higher $\mathrm{Cr}_{2} \mathrm{O}_{3}$ content $(14.70 \mathrm{wt} \%)$ than previously observed in the Orapa cluster, suggesting a very thick and highly depleted cratonic lithosphere at the time of diamond formation. Harzburgitic garnets are characterised by $\mathrm{LREE}_{\mathrm{N}}$ depletion, in contrast to $\mathrm{LREE}_{\mathrm{N}}$ enriched patterns for the bulk of Orapa harzburgitic garnets (Stachel et al., 2004). The sublithospheric inclusion suite reported here, consisting of a majorite garnet and possibly a Ca-rich orthopyroxene, is unique within the Orapa cluster and may provide a key link to the presence of exceptionally large diamonds at Karowe (Smith et al. 2017).

\section{References}

Deines, P., \& Harris, J. W. (2004). New insights into the occurrence of 13 C-depleted carbon in the mantle from two closely associated kimberlites: Letlhakane and Orapa, Botswana. Lithos, 77(1), 125-142.

Deines, P., Stachel, T., \& Harris, J. W. (2009). Systematic regional variations in diamond carbon isotopic composition and inclusion chemistry beneath the Orapa kimberlite cluster, in Botswana. Lithos, 112, 776-784.

Grütter, H.S., Latti, D. \& Menzies, A. (2006). Cr-saturation arrays in concentrate garnet compositions from kimberlite and their use in mantle barometry. Journal of Petrology, 47, 801-820.

Stachel, T., \& Harris, J. W. (2008). The origin of cratonic diamonds-constraints from mineral inclusions. Ore Geology Reviews, 34(1), 5-32.

Stachel, T., Viljoen, K. S., McDade, P., \& Harris, J. W. (2004). Diamondiferous lithospheric roots along the western margin of the kalahari craton - the peridotitic inclusion suite in diamonds from Orapa and Jwaneng. Contributions to Mineralogy \& Petrology, 147(1), 32-47.

Smith, E.M., Shirey, S.B., Nestola, F., Bullock, E.S., Wang, J.H., Richardson, S.H. \& Wang, W.Y., 2016. Large gem diamonds from metallic liquid in Earth's deep mantle. Science, 354, 1403-1405..

Stiefenhofer, J., Viljoen, K.S., Marsh, J.S., 1997. Petrology and geochemistry of peridotite xenoliths from the Letlhakane kimberlites, Botswana. Contributions to Mineralogy and Petrology, 127, 147158.

Sun, S., \& McDonough, W. (1989). Chemical and isotopic systematics of oceanic basalts: Implications for mantle composition and processes. Geological Society, London, Special Publications, 42(1), 313-345 